\title{
Ultrasonically diagnosed polycystic changes in the kidney of patients undergoing hemodialysis for more than 10 years and their possible relationship to the renin-angiotensin-aldosterone system
}

\author{
Yoshio Suzuki, M. D., Masahiro Miura, M. D., Shigeko Hara, M. D., Keihachiro \\ Kuzuhara, M. D., Hiroshi Nihei, M. D., Nobuhide Mimura, M. D., Mitsuru Hara, M. D.* \\ Kidney Center, Department of Pathology*, Toranomon Hospital \\ (昭和 59 年 9 月 3 日受付)
}

key words : hemodialysis, ultrasonic tomography, polycystic kidney, plasma renin activity, plasma aldosterone concentration

\section{〈Summary〉}

In 33 using the ultasonic tomography (Echo) and patients who had undergone hemodialysis for more than 10 years in our hospital, we investigated, by using the ultrasonic tomography (Echo) and CT scan methods, the influence of long-term hemodialysis on the polycystic changes in the kidneys and further studied the possible relationship of the changes to the renin-angiotensin-aldosterone system and to the occurrence of hypotension by means of the angiotensin II infusion test. Polycystic changes in the atrophic kidneys were observed in 31 of the cases $(94 \%)$ and were classified from the morphological standpoint by Echo into 5 types, I to V.

In Type I the kidney has a normal length of 8 to $9 \mathrm{~cm}$ and the whole kidney is replaced by multiple large cysts measuring 1 to $3 \mathrm{~cm}$ in diameter. In Type $\|$ the kidney is shorter (less than $6 \mathrm{~cm}$ ) and is replaced by multiple large cysts 1 to $3 \mathrm{~cm}$ in diameter. In Type $\mathrm{I}$ and $\mathrm{II}$, hardly any normal renal tissue is detected by Echo. The kidney in Type III is less than $6 \mathrm{~cm}$ in length and only a few cysts measuring less than $1 \mathrm{~cm}$ in diameter are found. Echo revealed that there is no cyst in Type IV. In Type V, the kidney size and cyst formation differ in the left and right kidneys.

There was no correlation between laboratory data underlying kidney disease and the morphological classification as Type 1 through $\mathrm{V}$.

Predialysis plasma renin activity (PRA) in Group $A(n=21)$, consisting of Types $I$ and $\|$, was statistically significantly higher than that in Group B $(n=10)$, consisting of Types III and IV $(p<0.01)$. The post/predialysis PRA ratio was markedly higher in Group A than in Group B. The renin secretion due to hemodialysis was found to be greater in Group A than in Group B.

There was no difference in plasma aldosterone concentration in Types I through $\mathrm{V}$.

There were 7 cases of hypotension defined by the WHO standard. All these 7 patients were hyperreninemic and hyperaldosteronemic. There was no significant difference in predialysis PRA between hypotensive cases and normal and hypotensive cases. However, when the mean postdialysis/mean predialysis PRA ratios were compared, the value in hypotensive cases was found to be significantly greater than that in normal and hypertensive cases, suggesting that the influence of hemodialysis on renin secretion was greater in hypotensive cases.

Critical doses estimated by the angiotensin II infusion test were more than $30 \mathrm{ng} / \mathrm{kg} / \mathrm{min}$ in all 7 hypotensive cases, seeming to suggest that hyperreninemia is a compensatory mechanism for this low vascular responsiveness. However, as the percentage of hypotensive cases in Group A was nearly equal to that in Group B, further study is necessary to determine if the cyst has a direct role in the compensatory mechanism in renin secretion.

鈴木 好夫 虎の門病院腎センター

勇 213 川崎市高津区梶攵谷 1-3-1 (044-877-5111) 


\title{
10 年以上血液透析の患者の超音波診断による腎囊胞形成様式と renin-angiotensin-aldoster- one $(R-A-A)$ 系の考察
}

\author{
鈴木 好夫 三浦 雅弘 原 茂子 葛原敬八郎 二瓶 宏 三村 信英 原 満* \\ 虎の門病院腎センター 同病理学科*
}

当院における 10 年以上透析の患者 33 名について超音波診断法により腎の囊胞形成を観察し，またこれら対象のう ち低血圧をしめす症例に angiotensin II（A II）注入テストを行い囊胞形成とR-A-A 系との関連を考察した。超音 波診断法で観察した 33 名中 31 名（94\%）に透析患者の萎縮腎に多囊胞性変化が認められ，囊胞形成様式を I， II， III，IV，V 型に分類した。すなわち腎長径が $8 \sim 9 \mathrm{~cm}$ で大型囊胞（直径 $1 \sim 3 \mathrm{~cm}$ ）で置換された I 型, 腎長径は 6 $\mathrm{cm}$ 以下で大型囊胞で置換されたII 型, 同III, IVは腎長径は $6 \mathrm{~cm}$ 以下と小さく前者は直径 $1 \mathrm{~cm}$ 以下の囊胞が数個 存在し, 後者には超音波診断法上囊胞がみつからないもの. V型は左右で別の型を示すもの. I V 型の別と臨床生 化学データおよび原疾患との関連はない，透析前 PRA は大型の囊胞をもつグループA（１型とＩ型の和）の方が小 さい囊胞および囊胞の見つからないグループB（III型とIV型の和）に比べ統計的に有意に高い（P<0.01)。PRAの 透析前後比はグループAがBよりも高い。すなわち renin 分泌に与える透析の影響はグループAの方ば大きい. 型別 分類と PAC の間に関係はなかった。 33 例中 7 例に WHO 基準の低血圧症が存在し，この 7 例すべてが高 renin, 高 aldosterone 血症であった。透析前PRA は低血圧症例と他の正常圧および高血圧症例との間に差はないが，PRAの 透析前後比は低血圧症例の方が明らかに高い. よって透析の renin 分泌に与える影響は低血圧症例において大きいと 考えられた。 A II注入テストによる critical dose は 7 例の低血圧症例全例で, 正常とされる $30 \mathrm{ng} / \mathrm{kg} / \mathrm{min}$ 以下より 高く, 10 年以上透析例の低血圧症例での PRA 高値は血管の低反応性の代償機序と考えられた。低血圧症の発生例数 が大型囊胞のグループA と小さい囊胞および囊胞の見つからないグループ B で同率であったため囊胞形成が renin 分 泌に関与するという直接の証明はえられなかった。

\section{Introduction}

It has been observed that first of all polycystic changes occur in the atrophic kidneys of patients udergoing long-term hemodialysis, that these changes gradually lead to an increase in volume, and that finally adenoma or adenocarcinoma frequently occurs in the kidney.

In 33 patients who had undergone hemodialysis for more than 10 years in our hospital, we investigated, by ultrasomic tomography the correlation between long -term hemodialysis and morphological classification of polycystic changes in the kidneys and further studied the possible role of the polycystic changes in the renin-angiotensin-aldosterone ( $\mathrm{R}-\mathrm{A}-\mathrm{A}$ ) system and in occurrence of hypotension, by the angiotensin II (A II) infusion test.

It has been found that anemia generally tends to improve according to prolongation of the hemodialysis period. Thus, erythropoietin levels in patients undergoing hemodialysis for more than 10 years were determined.

Patients and methods

The subjects in this study were 33 patients, 19 males and 14 females, who had undergone hemodialysis for more than 10 years in our hospital. The mean hemodialysis period was 13.2 years, and the longest was 16 years. The patients ranged in age from 25 to 71 years (average age 45.5 years). The underlying diseases were chronic nephritis (25 cases), preeclamptic toxemia (2 cases), gouty nephropathy (2 cases), Henoch-Schönlein purpura nephritis (1 case), rapidly progressive glomerulonephritis ( 1 case) and lupus nephritis (2 cases).

Seven ( 4 males and 3 females) of the 33 patients were diagnosed as hypotensive (below $99 / 59 \mathrm{mmHg}$ ) and were undergoing hemodialysis twice a week, total 12 to 13 hours, by means of a Cuprophan membrane hollow fiber type artificial kidney. Heparin was used as an anticoagulant during hemodialysis in all cases and the dialysate was acetate solution in 6 of the 33 cases and bicarbonate solution in the remainder. Ultrasonic tomography and CT scan.

Ultrasonic diagnosis was performed in the morning on patients who had fasted overnight, by means of a Toshiba SAL-20A sonia type ultrasonic tomograph and Aloka $210 \mathrm{~F}$ to determine the size of the kidney 
and the presence or absence of cysts or calcification in the kidney. A renal CT scan was also performed by using a Toshiba TCT-60A $=29$ type $\mathrm{x}$-ray computerized tomograph.

PRA and PAC:

The plasma renin activity (PRA) and plasma aldosterone concentration (PAC) were determined by radioimmunoassay 1 hour after the patient assumed a resting position. The normal levels after 1 hour of resting were as follows: PRA, 0.1 to $2.0 \Delta$ angiotensin I $\mathrm{ng} / \mathrm{ml} / \mathrm{h}$; and PAC, 2.8 to $13.6 \mathrm{ng} / \mathrm{dl}$. Blood was collected after 1 hour of rest before hemodialysis and at the termination of hemodialysis to determine PRA and PAC.

Angiotensin II infusion test:

Angiotensin II (CIBA) infusion tests were performed in the 7 hypotensive patients to investigate their vascular responsiveness. Intravenous drip infusion was conducted at $5 \mathrm{ng} / \mathrm{kg} / \mathrm{min}$ for 5 minutes and the A II dose needed to give a $20 \mathrm{mmHg}$ increase in diastolic pressure was decided on as the critical dose to be used as an indicator for vascular responsiveness. The blood pressure was measured at 1-minute intervals by an automatic blood pressure measuring device.
Erythropoietin :

Erythropoietin levels in the patients with hypotension were determined by hemoagglutinin inhibition assay (normal value, 7 to $36 \mathrm{mIU} / \mathrm{ml}$ ).

Hematocrit :

RBC, WBC, platelets, $\mathrm{Hb}$ and $\mathrm{Ht}$ were determined by using a Coulter counter.

Results

Ultrasonic tomography revealed polycystic changes in the kidney in all except 2 cases (94\%). These polycystic changes were classified from the morphological standpoint into 5 types which were designated as Types I, II, III, IV and V. The results are summarized in Table 1 . There were 15 patients with Type I, 10 males and 5 females whose average age was 48 years. Ultrasonic tomography revealed that the size of the kidney was normal $(8$ to $9 \mathrm{~cm}$ ) in length and that the whole kidney was replaced by a multiple large cysts measuring 1 to $3 \mathrm{~cm}$ in diameter (Fig. 1). There were 6 patients with Type II, 3 males and 3 females whose average age was 46 years. The kidney was small (less than $6 \mathrm{~cm}$ in length) and was replaced by multiple large cysts 1 to $3 \mathrm{~cm}$ in diameter (Fig. 2).

In Types I and II, hardly any normal renal tissue

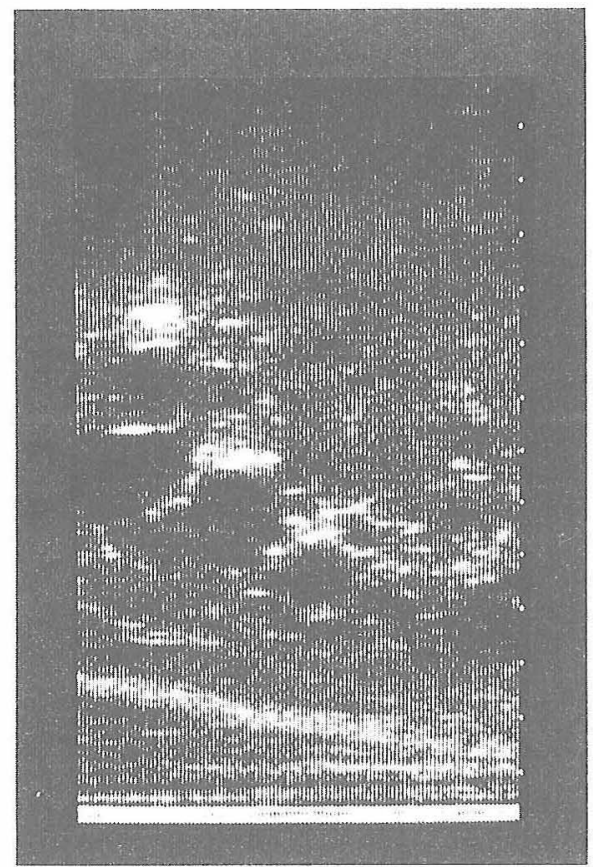

Fig. 1 Type I atrophic kidney on ultrasonic tomography

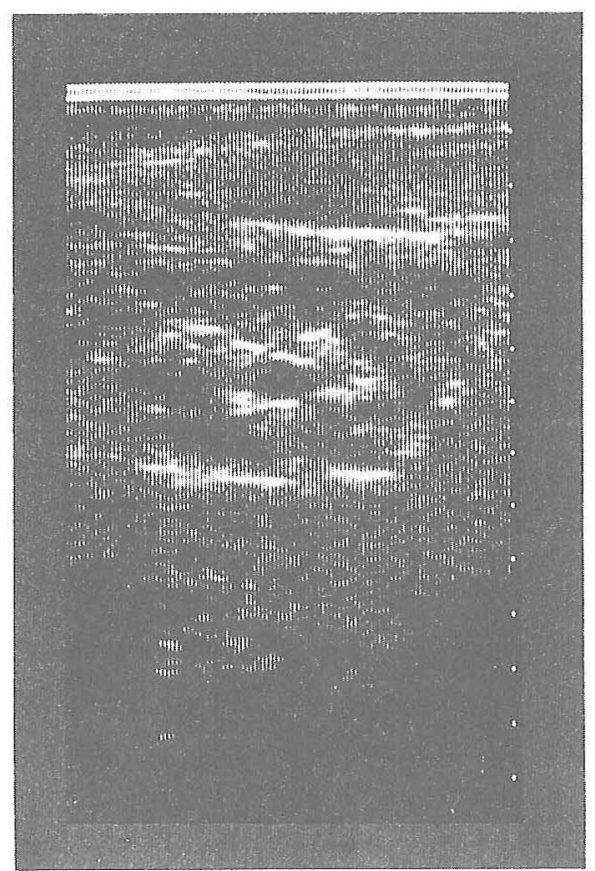

Fig. 2 Type II atrophic kidney on ultrasonic tomography 


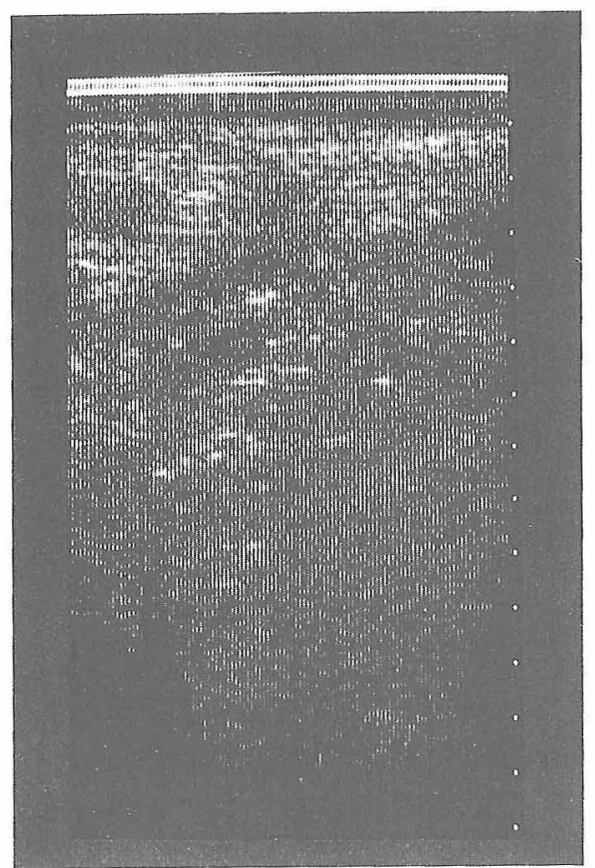

Fig. 3 Type III atrophic kidney on ultrasonic tomography

was revealed by ultrasonic tomography.

There were patients with Type III, 4 males and 4 females whose average age was 48 years. The kidney was less than $6 \mathrm{~cm}$ in length and only a few cysts measuring less than $1 \mathrm{~cm}$ in diameter were found (Fig. 3). Two patients 1 male and 1 female whose average age of 52 years, had Type IV. Ultrasonic diagnosis revealed that there were no cysts in these 2 cases (Fig. 4). Two patients, 1 male and 1 female whose average age was 59 years had Type $V$. It should be emphasized that the kidney size and cyst formation differed between the left and the right kidneys for example, Type I in the left and Type III in the right. Fig. 5 is a Type I kidney of an autopsy case. The size is normal owing to replacement by multiple large cysts. Scarcely any normal renal tissue was seen.

More than half of the total cases were those with large cysts, that is, Types I and II. There was no relationship between the type of cyst formation and the original disease, age, or duration of hemodialysis.

Blood pressure in all types was normal or borderline hypertensive and there was no relationship between blood pressure and types of cyst formation.

Hypotension was seen in 3 case of Type I , 2 cases

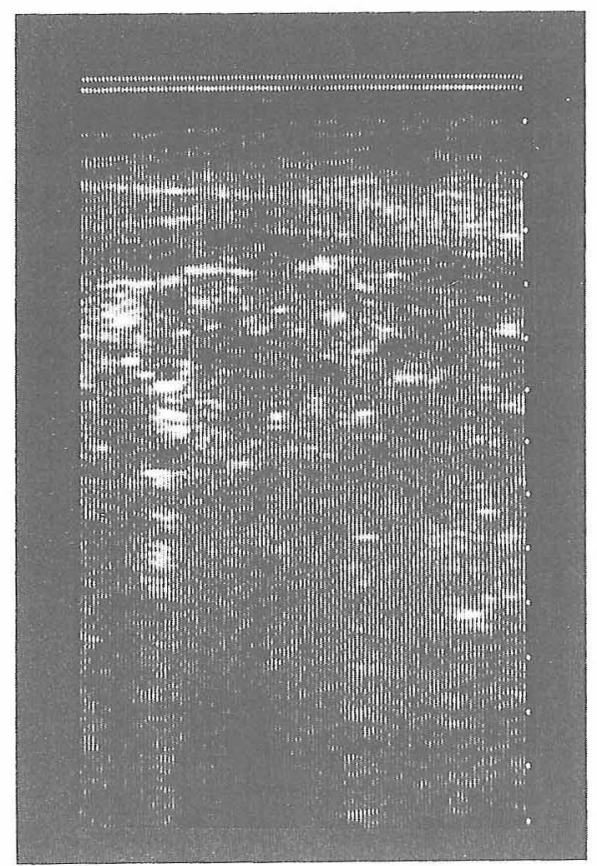

Fig. 4 Type IV atrophic kidney on ultrasonic tomography

of Type II, 1 case each of Types III and IV, and no case of Type V (Table 1). There was no renal cell carcinoma in any of the 33 cases. In contrast, multiple intrarenal stones were found in all types.

Echogenicity of the atrophic kidneys of all the subjects was greater than that of the renal sinus as well as the liver.

There was no correlation between laboratory data (serum total protein, BUN, creatinine, uric acid, total cholesterol and hematocrit) and the morphological classification of the kidneys by ultrasonic diagnosis as described above (data not shown).

The correlation between PRA and PAC and morphological classification of the kidneys determined by ultrasonic diagnosis was examined. The predialysis PRA in Type I was $3.0 \pm 0.8 \mathrm{ng} / \mathrm{m} / / \mathrm{h}$ and $4.1 \pm 1.7$, $1.6 \pm 0.35,1.2 \pm 0.4$ and $3.7 \pm 1.3$ in types II, III, IV, and $\mathrm{V}$ respectively.

The postdialysis PRA levels were $5.7 \pm 1.1 \mathrm{ng} / \mathrm{ml} / \mathrm{h}$, $10.0 \pm 2.3,1.9 \pm 1.0,2.8 \pm 0.9$ and $3.9 \pm 1.1$ in Type $\mathrm{I}$, II, III, IV and V, respectively.

The types with large cysts, i. e., Types I and II, appeared to have a high PRA.

As a matter of convenience, we divided the types 


\begin{tabular}{|c|c|c|c|c|c|c|c|c|c|c|c|c|c|c|c|}
\hline Type & 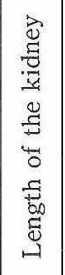 & $\begin{array}{l}\vec{w} \\
\dot{0} \\
\overrightarrow{0} \\
\dot{0} \\
\dot{z}\end{array}$ & 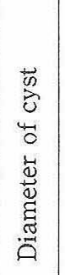 & 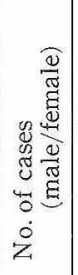 & $\begin{array}{c}\text { Original } \\
\text { disease* }\end{array}$ & * & 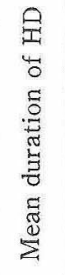 & 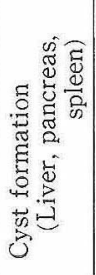 & 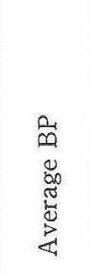 & 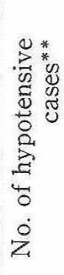 & 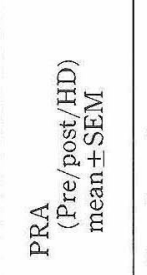 & 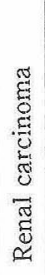 & 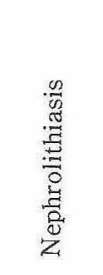 & 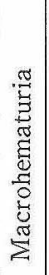 & 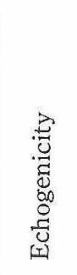 \\
\hline I & $\begin{array}{r}8-10 \\
\mathrm{~cm}\end{array} \mid$ & $\begin{array}{r}+++ \\
\text { (multi- } \\
\text { pl) }\end{array}$ & $\begin{array}{l}1-3 \\
\mathrm{~cm}\end{array}$ & $\begin{array}{c}15 \\
(10 / 5)\end{array}$ & $\begin{array}{lr}\mathrm{CN} & 12 \\
\mathrm{RPGN} & 1 \\
\mathrm{GN} & 1 \\
\mathrm{LN} & 1\end{array}$ & \begin{tabular}{l|l}
12 & \\
1 & 48 \\
1 & 48 \\
1 & $y .0$
\end{tabular} & $\begin{array}{r}13.2 \\
y\end{array}$ & no & $\begin{array}{l}144 / 80 \\
\mathrm{mmHg}\end{array}$ & 3 & $\begin{array}{l}3.0 \pm 0.8 \\
5.7 \pm 1.2 \\
\mathrm{ng} / \mathrm{m} / \mathrm{h}\end{array}$ & 0 & $\begin{array}{r}+++ \\
\text { (multi- } \\
\text { pl) }\end{array}$ & 0 & $\begin{aligned} & * * * * \\
&>\mathrm{RS}\end{aligned}$ \\
\hline II & $\begin{array}{l}7-8 \\
\mathrm{~cm}\end{array}$ & +++ & $\begin{array}{l}1-3 \\
\mathrm{~cm}\end{array}$ & $\left(\begin{array}{c}6 \\
(3 / 3)\end{array}\right.$ & $\mathrm{CN}$ & \begin{tabular}{l|l}
6 & 46 \\
$\mathrm{y} .0$
\end{tabular} & $\begin{array}{r}13.7 \\
y\end{array}$ & no & $\begin{array}{l}135 / 68 \\
\mathrm{mmHg}\end{array}$ & 2 & $\begin{array}{l}4.1 \pm 1.7 \\
10.0 \pm 2.3 \\
\mathrm{ng} / \mathrm{m} / \mathrm{h}\end{array}$ & 0 & +++ & 0 & $>\mathrm{RS}$ \\
\hline III & $\begin{array}{l}<6 \\
\mathrm{~cm}\end{array}$ & + & $\begin{array}{l}<1 \\
\mathrm{~cm}\end{array}$ & $\stackrel{8}{8}$ & $\begin{array}{ll}\mathrm{CN} & 5 \\
\mathrm{PI} & 1 \\
\mathrm{H}-\mathrm{SPN} & 1 \\
\mathrm{LN} & 1\end{array}$ & \begin{tabular}{l|l}
5 & \\
1 & 48 \\
1 & $y .0$ \\
1 & $y$
\end{tabular} & $\begin{array}{r}13.0 \\
y\end{array}$ & no & $\begin{array}{l}155 / 83 \\
\mathrm{mmHg}\end{array}$ & 1 & $\begin{array}{r}1.6 \pm 0.35 \\
1.9 \pm 1.0 \\
\mathrm{ng} / \mathrm{m} / \mathrm{h}\end{array}$ & 0 & +++ & 0 & $>\mathrm{RS}$ \\
\hline IV & $\begin{array}{l}<6 \\
\mathrm{~cm}\end{array}$ & - & $\begin{array}{c}0 \\
\mathrm{~cm}\end{array}$ & $\left(\begin{array}{c}2 \\
(1 / 1)\end{array}\right.$ & $\begin{array}{l}\mathrm{CN} \\
\mathrm{PI}\end{array}$ & \begin{tabular}{l|l}
1 & 52 \\
1 & y.o
\end{tabular} & $\begin{array}{r}13.5 \\
y\end{array}$ & no & $\begin{array}{l}129 / 66 \\
\mathrm{mmHg}\end{array}$ & 1 & $\begin{array}{l}1.2 \pm 0.4 \\
2.8 \pm 0.9 \\
\mathrm{ng} / \mathrm{m} l / \mathrm{h}\end{array}$ & 0 & +++ & 0 & $>\mathrm{RS}$ \\
\hline V & $\begin{array}{l}<6, \\
-10 \\
\mathrm{~cm}\end{array}$ &,++++ & $\begin{array}{r}<1, \\
-3 \\
\mathrm{~cm}\end{array}$ & $\underset{(1 / 1)}{2}$ & $\begin{array}{l}\mathrm{CN} \\
\mathrm{GN}\end{array}$ & \begin{tabular}{l|l}
1 & 59 \\
1 & y.o
\end{tabular} & $\begin{array}{r}14.0 \\
\mathrm{y}\end{array}$ & no & $\begin{array}{l}146 / 76 \\
\mathrm{mmHg}\end{array}$ & 0 & $\begin{array}{c}3.7 \pm 1.3 \\
\\
3.9 \pm 1.1 \\
\mathrm{ng} / \mathrm{m} / / \mathrm{h}\end{array}$ & 0 & +++ & 0 & $>\mathrm{RS}$ \\
\hline
\end{tabular}

${ }^{*} \mathrm{CN}$ chronic nephritis, RPGN rapidly progressive glomerulonephritis, GN gouty nephropathy, **below 99/55 mmHg (WHO standard) LN lupus nephritis, PI pregnancy intoxication, H-SPN Henoch-Schönlein purpura nephritis ***RS, renal sius

Table 1 Summary of cascs of atrophic kidney with history of more than 10 years of hemodialysis

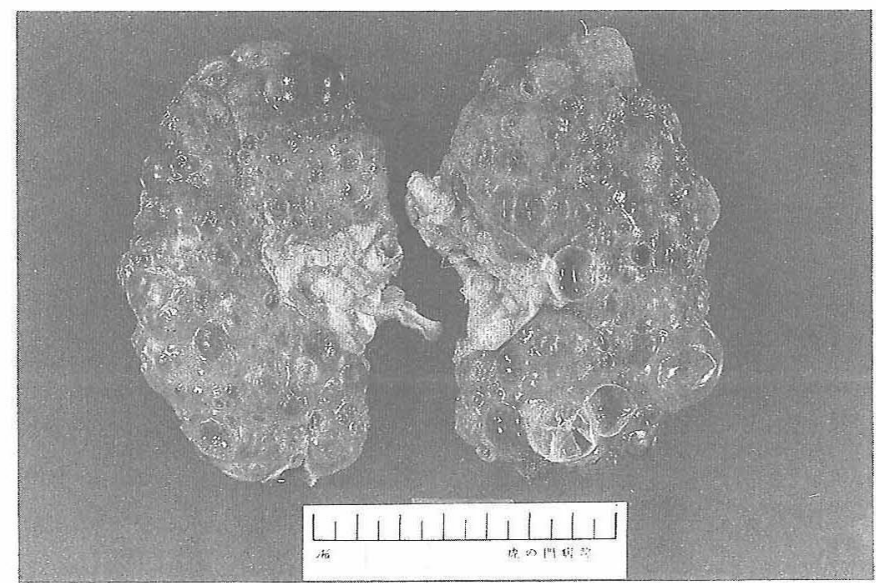

Fig. 5 Type I polycystic change of autopsied case. The kidney size was $10 \mathrm{~cm}$ in length and the kidney tisse was almost replaced by large cyst of 1 to $3 \mathrm{~cm}$ in diameter.

into two groups, of large cysts and small cysts. Group A with large cysts consisted of Types I and II and Group B with small cysts or substantial no cysts consisted of Types III and IV.

The predialysis PRA in Group A was $3.5 \pm 0.9 \mathrm{ng} /$ $\mathrm{m} l / \mathrm{h}(\mathrm{n}=23, \mathrm{~m} \pm \mathrm{SE})$ and that of Group B was $1.5 \pm 0.3$ 


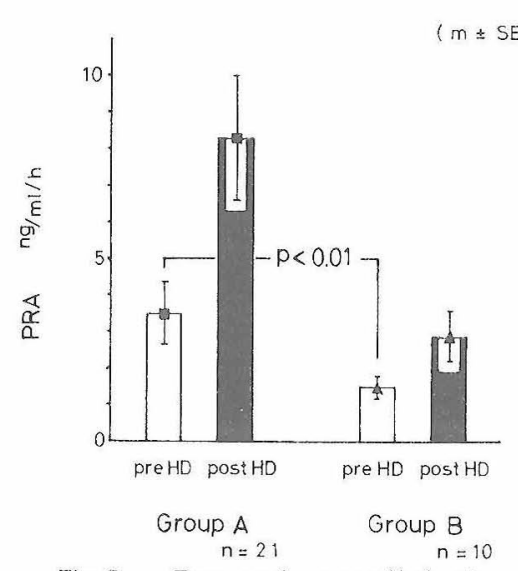

Fig 6 Pre-and postdialysis plasma rein activity (PRA) in Group A and Group B.

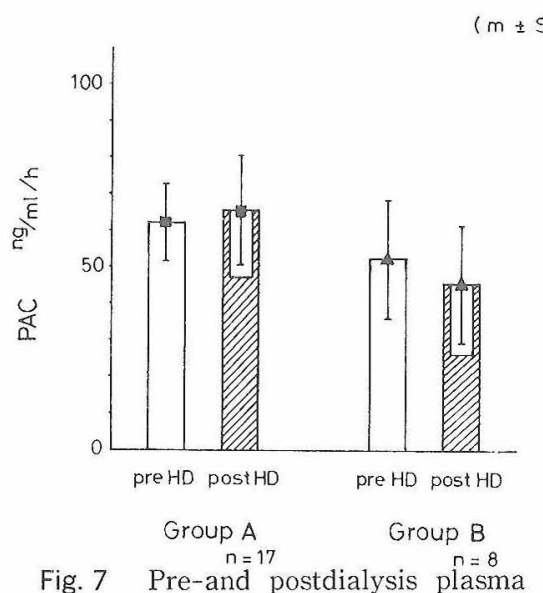

Fig. 7 Pre-and postdialysis plasma aldosteron concentration (PAC) in Group A and Group B.

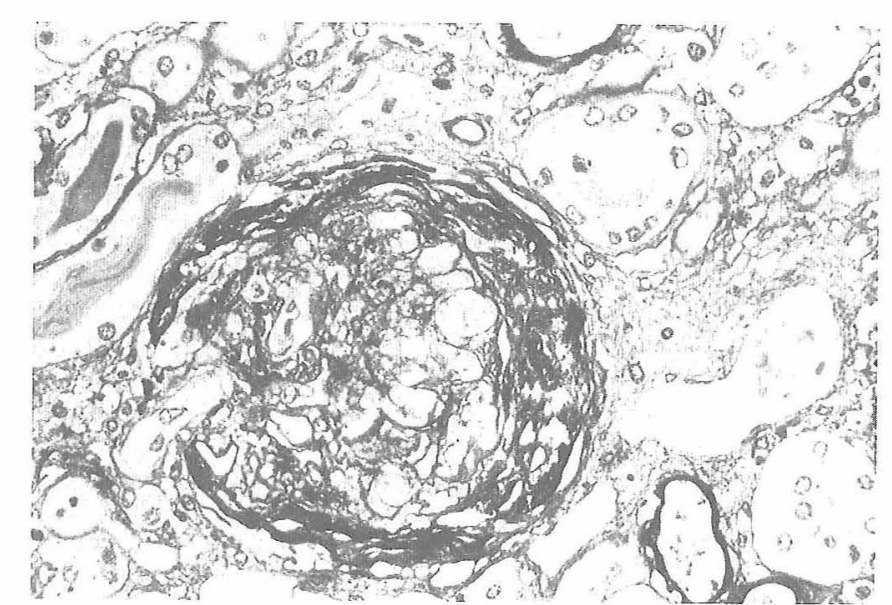

Fig 8. Renal tissue of Type I atrophic kidney in an autopsy case with history of more than 10 years of hemodialysis. There is a hyperplasia of the juxtaglomerular apparatus.

$\mathrm{ng} / \mathrm{m} / \mathrm{h} \quad(\mathrm{n}=10, \mathrm{~m} \pm \mathrm{SE})$. The predialysis PRA of Group A was statistically significantly higher than that of Group B by Student's t-test $(p<0.01)$.

The postdialysis PRA levels were $8.3 \pm 1.7$ in Group A and $2.9 \pm 0.7$ in Group B. The PRA was apparently higher in Group A. The mean postdialysis/mean predialysis PRA ratios was markedly higher in Group A than in Group B. The increased in renin secretion induced by hemodialysis was found to be greater in Group A than in Group B (Fig. 6).

The glomerulus was almost completely hyalinized and the interstitium was fibrous in a case of autopsied renal tissue of Type I. However it is possible to suggest an increase in renin secretion, because the juxtaglomerular apparatus was hyperplastic (Fig. 8).

The predialysis PAC in Group A was $62.4 \pm 10.6 \mathrm{ng} /$ $\mathrm{d} l(\mathrm{n}=17, \mathrm{~m} \pm \mathrm{SE})$, and that in Group B was $52.4 \pm 16.4$ $(\mathrm{n}=8, \mathrm{~m} \pm \mathrm{SE})$. The postdialysis PAC in Group $\mathrm{A}$ was $65.9 \pm 15.5 \mathrm{ng} / \mathrm{d} l$ and that in Group B was $45.8 \pm 16.0$. There was no significant difference between the two groups. No rise in PAC was found after hemodialysis.

Of the 7 cases of hypotension, 5 belonged to Group A and 2 to Group B. All these 7 patients were hyperreninemic $(30.0 \pm 0.38, \mathrm{~m} \pm \mathrm{SE})$ and hyperaldosteronemic $(77.0 \pm 21.3, \mathrm{~m} \pm \mathrm{SE})$. They showed hypotension in spite of their hyperreninemia, a paradoxical 
finding. When the predialysis PRA of the hypotensive cases was compared with that of normal and hypertensive cases in Group A, it was found that the predialysis PRA in hypotensive cases was $3.24 \pm 0.40$ whereas that of normal and hypertensive cases was $4.09 \pm 4.10$. There was no significant difference, however, when the mean postdialysis/mean predialysis PRA ratios were compared; the value was 3.38 in hypotensive cases and 2.0 in normal and hypertensive cases. This shows that the rise in PRA due to the influence of
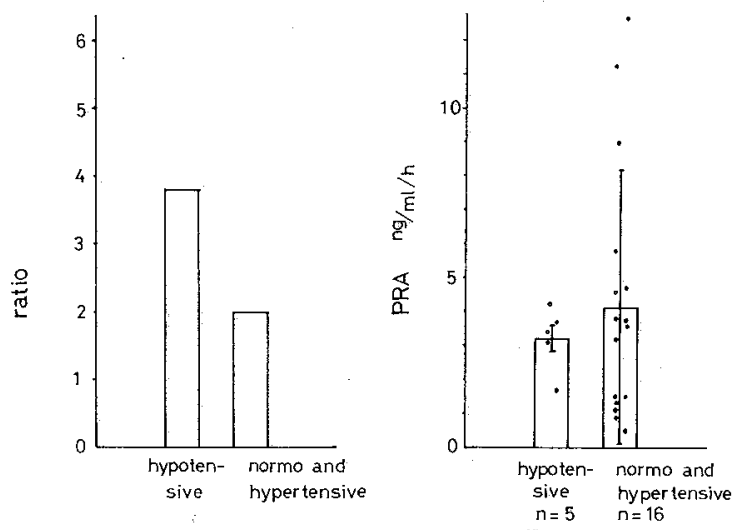

Fig 9. (left) Comparison of predialysis PRA between hypo-and normo-to hypertensive cases in Group A.

(right) Comparison of the mean post/ mean predialysis PRA ratios between hypo-and normo-to hypertensive cases in Group A. hemodialysis was greater in hypotensive cases (Fig. 9).

It is well known that the hematocrit level improves according to prolongation of the hemodialysis period. In our experience, the mean hematocrit level increased gradually, i. e., $21.1 \%(n=14)$ within 1 year of the beginning of hemodialysis, $22.5 \%(n=16)$ from 3 to 4 years, $24.0 \%(n=19)$ from 7 to 8 years and $25.4 \%$ over 10 years. In order to elucidate the relationship between duration of hemodialysis and erythropoietin the level, erythropoietin levels in 6 patients who had undergone hemodialysis for more than 10 years were determined. The erythropoietin levels were within normal range in all the patients. There was no patient with a level below normal, even though erythropoietin levels should be low in such patients with renal failure.

When the blood pressure of the patients undergoing hemodialysis for more than 10 years was compared with that of the patients who had had hemodialysis for only 3 months, both systolic and diastolic blood pressure were lower in the former than the latter (Fig. 10). Especially hypotension (below $99 / 55 \mathrm{mmHg}$ ) appeared in the patients undergoing hemodialysis for more than 10 years but was not seen in the patients with short-term dialysis.

Hypotension is usually accompanied by hyperreninemia in long-term hemodialysis patients. To investigate the causative factors of hypotension ac-

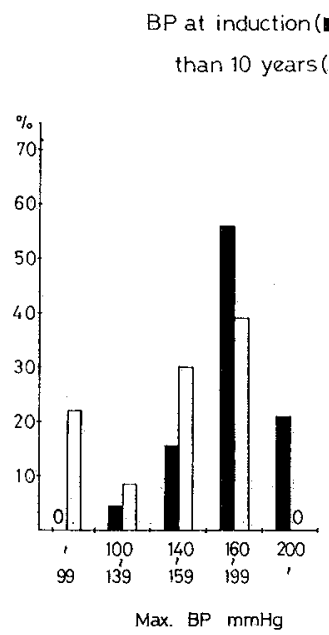

$=89)$ and $\mathrm{BP}$ at more

than 10 years $(\square n=29)$ of hemodialysis
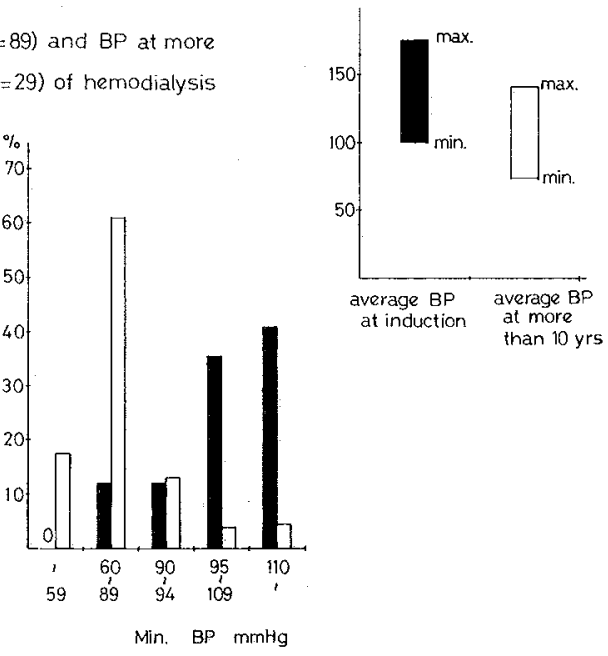

Fig. 10 Blood pressure at induction (within 3 months) $(n=89)$ and at more than 10 years $(n=29)$ of hemodialysis. 
companied by hyperreninemia, an A II infusion test was conducted to determine the blood vessel reponsiviness. A II, $5 \mathrm{ng} / \mathrm{kg} / \mathrm{min}$, was intravenously infused at constant speed by using an infusion pump, and the concentration was increased by $5 \mathrm{ng} / \mathrm{kg} / \mathrm{min}$ every 5 min. During the test, 2 patients complained of a feeling of heavy pressure in the pectoral region, but it disappeared after termination of the infusion.

When the volume of $\mathrm{A}$ II to raise the diastolic pressure by $20 \mathrm{mmHg}$ was decided as the critical dose, the results shown in Table 2 were obtained. The critical dose was more than $30 \mathrm{ng} / \mathrm{kg} / \mathrm{min}$ in all the cases. The normal response is below $30 \mathrm{ng} / \mathrm{kg} / \mathrm{min}$. The mean $\pm \mathrm{SE}$ of the critical dose in the hypotensive patients was $57.4 \pm 12.8(\mathrm{n}=7)$, and that in normotensive patients. undergoing hemodialysis for more than 10 years was 25.0 and 10.3 respectively. The critical dose was high in the hypotensive cases with high predialysis renin levels.

\section{Discussion}

It has generally been confirmed that cysts develop in the kidneys of long-term hemodialysis patients with parenchymatous renal disease. In our study polycystic changes occurred in the kidneys of 31 of 33 patients (94\%) who had undergone hemodialysis for more than 10 years. It was considered in the past that the atrophy of the kidney progressed further during kidney the long-term hemodialysis period. However since Dunnill $^{1)}$ and Millard ${ }^{1)}$, reported on acquired cystic lesions of the kidney, it has been apparent that cystic changes occur in the atrophic kidney with renal failure in long-term hemodialysis patients and the volume of the kidneys is increased ${ }^{2)}$. In addition, adenocarcinoma has been found to occur in the remaining kidney, which should have great influence on the prognosis of hemodialysis patients ${ }^{3}$.

Ota et al. $^{4)}$ reported, after a survey of malignant tumors in dialysis patients in Japan, that 32 cases of malignant tumors in the renal or urinary tract system were diagnosed clinically from 1972 to 1979 and that this incidence was 5.7-fold higher than in non -hemodialyzed males, and 11.7-fold higher than in non -hemodialyzed females. According to the analytical study on renal cancer in hemodialysis patients in Japan $^{5}$, 34 cases (25 males and 9 females) were diagnosed as renal cancer in February 1982. The average age of these patients was 47.9 years, the average hemodialysis period was 50.1 months, general metastasis was found in 7 cases, and the underlying disease in 28 cases was chronic glomerulonephritis. Fortunately, there has been no renal cancer among our patients.

The fact that there were various types of cyst formation in long-term hemodialysis patients seemed to be disregarded. According to our results, the kidneys were replaced by large cysts, which increased in volume and were classified as Group $\mathrm{A}$ in which hardly anyrenal parenchyma was seen by either ultrasonic tomography or CT scan, or Group B in which atrophic kidneys were present with diffused small cysts. Group A was composed of 21 cases and Group B of 10 cases. It was surprising that there were no cysts in 2 of the 33 cases. It seems to us that a cyst is not formed by only the factors of the body fluids of patients with renal failure.

Predialysis PRA in Group A, i. e., Type I and Type II, is significantly higher $(\mathrm{p}<0.01)$ than in Group B, i. e., Type III and type IV. The mean postdialysis/mean predialysis PRA ratios was 2.37 in Group A and 1.9 in Group B. This finding seems to suggest that the polycystic change increases renin secretion.

Erythropoietin levels were high in all 6 cases, in which they were determined suggesting that polycystic changes mean a compensatory point of erythropoietin secretion.

The underlying diseases of the patients undergoing hemodialysis for more than 10 years were chronoic nephritis (18 cases), of gouty nephropathy (1 case), lupus nephritis ( 1 case) and rapidly progressive glomerulonephritis (1 case) in Group A (1 case), whereas in Group B they were chronic nephritis (6 cases), lupus nephritis (1 case), Henoch-Schönlein purpura nephritis (1 case) and preeclamptic toxemia ( 2 cases). The diseases of the 2 patients with no cysts were chronic nephritis and preeclamptic toxemia. Therefore, cyst formation is indifferent to the underlying disease. As stated above, it is unlikely that the cystic changes in the kidney of the patients undergoing hemodialysis for more than 10 years are caused by a factor of the body fluid or the kind of underlying disease.

There were 7 cases of hypotension among the 33 


\begin{tabular}{l|c|c|c|c|c|c}
\hline Patient & Name & Sex & $\begin{array}{c}\text { Age } \\
\text { (yrs) }\end{array}$ & $\begin{array}{c}\text { Dialysis } \\
\text { history } \\
\text { (yrs) }\end{array}$ & Group & $\begin{array}{c}\text { Critical dose } \\
\mathrm{ng} / \mathrm{kg} / \mathrm{min}\end{array}$ \\
\hline 1 & & $\mathrm{~m}$ & 40 & 15 & $\mathrm{~A}$ & 137.2 \\
2 & & $\mathrm{~m}$ & 61 & 12 & $\mathrm{~A}$ & 32.6 \\
3 & & $\mathrm{~m}$ & 43 & 14 & $\mathrm{~B}$ & 38.6 \\
4 & & $\mathrm{~m}$ & 34 & 15 & $\mathrm{~A}$ & 39.6 \\
5 & & $\mathrm{f}$ & 46 & 13 & $\mathrm{~B}$ & 54.0 \\
6 & & $\mathrm{f}$ & 42 & 16 & $\mathrm{~A}$ & 81.9 \\
7 & & $\mathrm{f}$ & 34 & 12 & $\mathrm{~A}$ & 60.5 \\
\hline Group A=Type I + II Group B=Type III + IV \\
Table 2 Angiotensin II infusion test for hypotensive \\
patients
\end{tabular}

patients undergoing hemodialysis for more than 10 years. Hyperreninemia, however, was observed in all these patients. To determine the necessity to enhance the renin secretion, vascular responsiveness was investigated by the A II infusion test.

The critical dose was found to be higher than the normal level in all of 7 of the hyperreninemic hypotensive patients and a decrease in vascular responsiveness was observed. That is, the increase in renin secretion seems to be caused by a compensatory mechanism in hypotensive patients due to decreased vascular responsiveness. From the fact that increase in renin secretion was observed in Group A patients whose atrophic kidneys were replaced by large cysts, as indicated by ultrasonic tomography, it is suggested that the compensatory mechanism may be involved in cyst formation.

\section{Conclusion}

With patients who had undergone hemodialysis for more than 10 years, we investigated the influence of long-term hemodialysis on the polycystic changes in the kidney by using the Echo and CT scan methods and further studied the possible relationship of the polycystic changes to the R-A-A system and to the occurrence of hypotension, by the angiotensin II infusion test. The folowing results were obtained:

1) Polycystic changes in the kidney were observed in 31 of 33 cases $(94 \%)$ and were classified into 5 Types, I, II, III, IV and V, on the basis of ultrasonic examination.

2 ) Predialysis PRA was significantly $(\mathrm{p}<0.01)$ higher in patients with large cysts (Types I and II) than in those with small cysts (Types III and IV).

3 ) There was no difference in PAC in Types I -IV, from the morphological standpoint.

4) The critical dose in the angiotensin II infusion test was elevated in all 7 hyperreninemic hypotensive cases. This finding seems to suggest that hyperreninemia is a cause of the compensatory mechanism for this low vascular responsiveness. However, as the percentage of hypotensive cases in Group A was nearly equal to that in Group B, further study is necessary to determine if the cyst has a direct role in the compensatory mechanism in renin secretion.

\section{References}

1) M. S. Dunnill, P. K. Millard : Acquired cystic disease of the kidneys ; a hazard of long-term intermittent maintenance hemodialysis. J. Clin. Path., $30: 868-877,1977$.

2) Editorial : Acquired cystic disease of the kidney. Lancet, 2 : 1063, 1977.

3) I. Ishikawa, Y. Saito, Z. Onouchi, H. Kitada, S. Suzuki, S. Kurihara, T. Yuri and A. Shimada : Development of acquired cystic disease and adenocarcinoma of the kidney in dialysis patients. Clin. Nephrol., $14: 1-6,1980$.

4) K. Ota, N. Yamashita, T. Suzuki and T. Agishi : Malignant tumors in dialysis patients: A nationwide survey. PEDTA, 18 : 724-730, 1981.

5) I. Ishikawa, Y. Fukuda and S. Shinoda : Renal cancer in hemodialysis patients--Present state in Japan. Jap. J. Nephrol., 25 : 622, 1983. 